\title{
CORPORATE SOCIAL RESPONSIBILITY AND CONSUMER ETHICS FROM THE PERSPECTIVE OF YOUNG CONSUMERS IN CROATIA
}

\author{
Blazenka Knezevic \\ Department of Trade, Faculty of Economics and Business, University of Zagreb, \\ Trg J. F. Kennedy 6, 10000 Zagreb, Croatia \\ E-mail: bknezevic@efzg.hr
}

\begin{abstract}
Corporate Social Responsibility and consumer ethics are two research fields addressing similar issues, but from two different perspectives. As both rely on ethical standards of individuals involved in management or individuals involved in retail shopping, there are numerous research studies that investigate attitudes of various groups of persons regarding individual ethical values. In this paper both concepts are described and discussed. Upon analysed literature, the questionnaire is created and the survey took place on students of Business Administration and Economics in Croatia, as future managers and young consumers. The aim of the paper is to evaluate their perception towards ethical principles of business conduct described in literature in afore mentioned research fields.
\end{abstract}

Keywords: corporate social responsibility, business ethics, consumer ethics, stakeholders, young consumers, Croatia.

JEL Classification: M14; L81; D12.

\section{Introduction}

Broadly defined, Corporate Social Responsibility (CSR) is a management concept whereby companies integrate social and environmental issues in their business operations and strategies. In addition, CSR means conducting business in highly ethical manner and to contribute to sustainable economic development. It involves all relevant stakeholders and aiming to improve their lives in way that are good for business, local community and society in general.

There are five key elements of socially responsible company (Branko, Rodrigues 2007): (1) it has responsibility beyond production of goods and services and there is a social contract between business and society, (2) company is involved into social problem solving, (3) company's perspective is broader than shareholders' perspective, (4) it has impact beyond marketplace transactions, (5) it serves to a wide range of human values, not only economic values.

Even in the historical microeconomic literature, starting yet in 15th century, CSR topics, such as ethics, poverty reduction and responsibility of businessmen towards different stakeholders, were addressed (see Knezevic et al. 2012). But, yet in the recent period, corporate social responsibility (CSR) has become more important as a component of corporate strategy at the domestic and global level. Therefore, a bunch of research studies are approaching to three main aspects of CSR: (1) economic, (2) environmental and (3) social aspect.

On the other side, consumer ethics as a term refers to an ethical behaviour of ordinary consumers while purchasing in retail stores or online. Usually, research in this field addresses issues such as consumers' in-store and after purchase misbehaviour and attitudes of consumers towards shopping malpractices. But there are also some studies dealing with consumer activism and consumer awareness on ecological aspects of retailing.

$\mathrm{Up}$ to our knowledge, there is a scarcity of primary research studies in fields of CSR and consumer ethics that are dealing with attitudes of consumers in Croatia, especially younger population. Therefore, the main goal of this paper is to contribute to this field by primary data in this particular market. Thus, the aim of the paper is to evaluate perception of young consumers in Croatia towards ethical principles of business conduct described in literature in fields of CSR and consumer ethics.

The paper consists of 3 main sections and it is starting with a literature review, firstly on general aspects of Corporate Social Responsibility, secondly on CSR stakeholders, thirdly on general aspects of consumer ethics. The literature review ends with a review of research studies taken in fields of CSR and consumer ethics. 
Next part of the paper is the description of survey methodology and sample and then, the chapter "Results and discussion" gives an insight into attitudes and perceptions of young consumers on CSR and consumer ethics issues.

\section{Literature review}

\subsection{Corporate social responsibility - definition, scope and embeddedness into Business strategy}

According to the European Commission (2002), "Corporate Social Responsibility (CSR) refers to companies taking responsibility for their impact on society. As evidence suggests, CSR is increasingly important to the competitiveness of enterprises. It can bring benefits in terms of risk management, cost savings, access to capital, customer relationships, human resource management, and innovation capacity". In a long run, companies have to focus on contribution to society, rather than only to profit generation (Kotler, Keller 2006). In this sense, the social responsibility of business encompasses the economic, legal, ethical, and discretionary expectations that society has of organizations at a given point in time (see Carroll 1979).

Generally, CSR is understood as a process of reaching the balance between (1) economic, (2) environmental and (3) social imperatives. In the literature, this concept is often referred to as the "triangle of sustainable development". All three imperatives are equally important and ensure efficient utilization of resources, in order to reach sustainability of the company in a long-run (Shaw 1999). The aim of social responsibility is to create higher standards of living, while preserving profitability of the corporation, for people within and outside of corporation (Hopkins 2005).

On the basis of the World Bank research from 2007, authors (Rudawska, Witowska 2012) claim that companies are motivated for CSR activities in order to earn a better reputation, develop better relationships with local communities, build up the brand image, and improve relationships with their employees.

CSR incorporates undertaking the responsible activities that goes beyond the legal, market and economics requirements and that CSR promote values such as freedom and human rights, democracy, diversity, minority protection, reduction of poverty and inequality between rich and poor, health and quality of life (see Renko et al. 2009). CSR criteria can be grouped into five main areas (Scott 2007): (1) responsibility to the community and society, (2) promoting democracy and citizenship, (3) reduc- ing poverty and the inequality between rich and poor, (4) employee rights and working conditions, (5) ethical behaviour.

Research studies are claiming that there is a positive impact of CSR on business performance of the company. For instance, research study (Preston, O'Bannon 1997) found that CSR is positively connected with financial performance; while study (Stanwick, Stanwick 1998) established positive relationship between corporate performance and good relationship with stakeholders; authors (Ruf et al. 2001) find that there is positive relationship between change in CSR and increase in sales and returns on sales; research (Peloza 2006) established a relationship between CSR and increase in profits and value of companies. Moreover, empirical research study by authors (Sun, Suebs 2013) provided an empirical evidence of the positive influence of CSR on productivity.

Human health and environment protection are growing in importance and that various market subjects are finding ways how to implement policies and practices of their protection starting from United Nation Conference on Environment and Development held in 1992. in Rio de Janerio (see Moore, Vamvakidis 2007). Awareness of public on health and environment issues grows over time and, therefore, companies have to implement environmental policies into their business strategies in order to preserve and enforce a positive public image.

Companies should implement CSR policies into strategic objectives in a meaningful and logical manner, providing a measuring system that will allow to objectively assessing benefits during their implementation. ISO 26000, Social capital for Economy points to key benefits of CSR that companies should focus to: (a) building competitive advantage with the focus on long term stable growth, (b) increasing resistance towards possible crisis situations, (c) fostering organizational culture based on transparent, collaborative and high ethical standards, (d) formation and improvement of the positive image, including different internal and external stakeholders, including local community and wide public, (e) maintaining the positive perception of job seekers and increasing employee satisfaction and motivation, (f) keeping the positive perception of the company from the aspect of the existing and potential investors.

Similarly, the publication Business Impact (2000) points out five key principles of CSR policies: (1) to treat employees fairly and equitable, (2) to operate ethically and with integrity, (3) to respect human rights, (4) to sustain environment 
for future generations and (5) to be a caring neighbour in local community.

\subsection{The stakeholders perspective of corporate social responsibility}

The concept of corporate social responsibility means ethical treat and responsibility to various stakeholders who have various interests in the business: investors, employees, customers, suppliers and business partners, government, society and community, activists etc. A stakeholder of a corporation is defined as an individual or a group which either is harmed by, or benefits from, the corporation; or whose rights can be violated, or must be respected by the corporation (Cheng, Ahmad 2010).

Within the broad spectrum of stakeholders, they can be broken into two different groups: primary stakeholders and secondary stakeholders (Moir 2001). Primary stakeholders directly affect the success and failure of the company, they directly benefit from a positive performance of the company but they are, also, directly harmed if the company's business is not conducted properly. Therefore, primary stakeholders are those who have a direct interest in performance and business actions of the company. Examples of primary stakeholders are: owners, and shareholders, managers, employees, customers, and suppliers. Secondary stakeholders can influence, both positively and negatively, the actions of the organization. They support the activities of the company in order to achieve the positive effects of business actions or hinder the activities in order to prevent the negative consequences that could arise from the business activities of the company. Examples of secondary stakeholders are: government agencies, regulation agencies, trade unions, labour unions, political groups, social groups, and the media.

Authors (Evans, Sawyer 2010) claim that a business will convince stakeholders that they are serious on CSR if they can demonstrate that their policies achieve the desired social, environmental and ethical outcomes. Besides that a considerable number of organizations claim to practice CSR, but many do not act in a socially responsible manner (Evans, Sawyer 2010). In the practical research (Evans, Sawyer 2010) the interview research on the sample of owners and managers is applied towards five key stakeholders in small and medium companies, those are: customers, suppliers, employees, local community and environment.

Similarly, study (Ditlev-Simonsen, Wenstop 2013) briefly explain five major stakeholders' roles, i.e. the roles of: (1) owners, (2) employees, (3) customers, (4) non-government organizations, (5) government. They explain that owners (shareholders) have the primary responsibility of CRS implementation because they give direct instructions to the board of directors when setting the business strategy. Such approach is supported in paper (Alrousan et al. 2015).

Employees are searching for employers with a long term orientation that behave on high ethical principles regarding workers. Moreover, they are willing to get more engaged if they see a wide range of values beyond economical values. Employees are getting more motivated when they believe in company's mission and goals. Customers are the key motivators because in accordance to their buying behaviour and increased social responsibility they will directly influence the income of the company. Non-government organizations NGOs have the power to use traditional and social media to change the corporate reputation and they may create positive or negative media coverage. Finally, government has the power to change or introduce laws and regulations regarding CSR, but also to introduce actions and initiatives to support CSR practices.

In implementing and fulfilling of CSR strategies, companies are expected to engage stakeholders through various initiatives and actions. Therefore, CSR strategies of large companies points out stakeholders in slogans and marketing communication. The research by authors Evans, Sawyer (Evans, Sawyer 2010) showed that many small businesses are involved in CSR practice without knowing that they are actually doing that, but they are implementing various "the right-to-do" actions towards stakeholders because it gives them a sense of pride, foster long term values, improves the image of the company and may lead to cost savings.

There are several key factors that influence the growth of implementation of CSR into business strategies and are concerned with stakeholders (Cheng, Ahmad 2010): (1) consumer demands for "pro-CSR" goods and services is increasing, (2) non-governmental organizations (NGOs) are increasingly sophisticated and coordinated, (3) employees are more concerned about social values of their employer, their expectations are higher, (4) there is the ripple effect up, down and across the supply chain and it is often based on implementation of minimum standards of operation, (5) governments enforce and support CSR policies, (6) there are more and more CSR activists which promote issues and initiatives towards environment, social inclusion and ethics, (7) good 
community relations are becoming crucial for sustaining business activity throughout partnership and fulfilling social demands of the local community.

The paper by Bosch-Badia et al. (Bosch-Badia et al. 2013) analyse a wide range of literature on CSR and they conclude that (1) the theoretical thought on CSR can be synthetized into three main stages: philanthropy, value creation contribution and integration of CSR into corporate strategy throughout shared values, and (2) studies on contribution of CSR to Corporate Finance Performance (CFP) throughout the time show that on a long run there is a positive correlation between CSR and CFP when CSR is focused on stakeholders. Therefore, CSR values attract investors who look for long run profitability.

CSR is no longer concept with importance only to large firms but, also, it is important for small and medium companies i.e. SMEs (Szarucki 2013). Based on the comprehensive literature review and in-depth analysis of secondary data for Poland, drivers and impediments for CSR activities in Polish companies can be distinguished, and those drivers are (Szarucki 2013): personal moral and ethical principles of small business owners, improving company's image and market position and awareness of customers' needs and requirements; while impediments are: lack of financial resources, lack of time and low staff skills.

\subsection{Consumer ethics - definition and scope}

The area of consumer ethics concerns the ethical issues that arise when ordinary consumers acquire, use, and dispose of conventional consumer products (according to Holbrook 1994). The research study (Holbrook 1994) claims that such aspects of consumption raise various ethical questions related to the potential consumer misbehaviour.

Al-Khatib et al. (1997) point out that the two most commonly areas in the field of consumer ethics are shoplifting and ecologically related consumption.

One of the most cited models in the field of consumer ethics is given Hunt-Vitell model (Hunt, Vitell 1986) who claims that in his/hers behaviour consumer apply either (1) deontological or (2) teleological evaluation. Deontological evaluation is concerned as the process where an individual evaluates the inherent rightness or wrongness of set of alternatives as possible courses of action. In such way ones action is driven by personal values or rules of behaviour. On the other hand, teleological evaluation process, individuals will evaluate possi- ble behaviours by considering others, therefore, before taking an action he/she will consider (according to Hunt, Vitell 1986): (1) the perceived consequences of each alternative for various stakeholder groups; (2) the probability that each consequence will occur to each stakeholder group; (3) the desirability or undesirability of each consequence; and (4) the importance of each stakeholder group.

Contemporary consumers' sophistication, i.e. the fact that consumers are better informed, more educated and more aware of consumer rights and product requirements, is no guarantee that consumers actually will participate in wise or ethical buying practices (according to Carrigan, Attalla 2001). Information on ethical/unethical behaviour of a company does not necessarily lead a consumer to boycott the unethical firm or its products (as it is argued by Carrigan, Attala 2001). In addition, according to the same research study (Carrigan, Attala 2001), consumers may express a desire to support ethical companies, and punish unethical companies, but their actual purchase behaviour often remains unaffected by ethical concerns.

\subsection{Research studies on attitudes towards corporate social responsibility and consumer ethics}

There are numerous studies of CSR business practices explaining how companies apply CSR into their business strategy and how do they behave towards different stakeholders; we mentioned some of them in previous part of the paper. But, also, there are some studies on attitudes towards CSR and business ethics in general so here we are going to give some examples.

ATBEQ (Attitudes Toward Business Ethics Questionnaire) that consist 30 statements on business attitudes was applied on the sample of management students in USA and Israel (see Preble, Reichel 1988). They (Preble, Reichel 1988) found out that respondents from both countries place considerable importance on morals in business and that there are only few significant differences.

Shields et al. (2013) used the same Questionnaire (ATBEQ) with suggested five philosophical categories (see Bageac et al. 2011) to examine differences between USA and Japanese students. Those categories are: Machiavellian, Social Darwinism, Ethical Relativism, Legalism and Moral Objectivism. On the basis of analysis they (Shields et al. 2013) suggest that the attitudes towards business ethics of students in USA and Japan differ significantly and that Japanese students express 
stronger agreements on less benign philosophical categories such as statements concerned with Moral Objectivism.

ATBEQ was applied onto SME owners in South Africa and analysed and explained different perspectives toward Business Ethics and CSR between local and immigrant owners (see Fatoki, Chillya 2012). They (Fatoki, Chillya 2012) claim that both groups recognize importance of business ethics and CSR and that there is no statistically significant difference between those two groups of owners. From the aspect of CSR, owners of SMEs perceive importance of CSR in improvement of local community's quality of life, but also improvement of long-run profitability of a company.

In addition ATBEQ was applied on business sudents in US and Vietnam (see Nguyen, Pham 2015) and significant differences in attitudes towards business ethics between those two countries are discovered.

Among all statements on entrepreneurial orientation, in study (Claar et al. 2012) question on orientation towards helping others was included, and they found out that respondents have a high level of agreement with the statement "If I see someone in trouble, I help out in any way I can" in all three analysed countries (Poland, Armenia and USA).

On the other hand, consumer ethics is covered by research studies from different perspectives. Numerous authors covered topics such as socially responsible consumption in general, consumer selfrestraint, voluntary simplicity in conserving energy, customer boycotts, compulsive consumption, or consumer in-store misbehaviour (see Holbrook 1994).

Muncy, Vitell (1992) made a significant contribution to this research area by developing Consumer Ethics Scale CES which has been applied to different markets over the time. In the paper (Polonsky et al. 2001) a list of countries where the CES is applied in research studies of consumer ethics is given. Those countries are: Egypt, Austria, Ireland, Lebanon, South Africa and USA.

Vitell et al. (2001) analysed Hunt-Vitell model of consumer ethics on adult consumers and came up to conclusion that consumers, when making buying decisions, rely more on deontological evaluation than teleological, i.e. they takes into consideration their own ethical norms and values, rather than thinking on others and consequences of their actions.

Authors (Babakus et al. 2004) examined individual tolerance for unethical consumer behaviour such as shoplifting and in-store and after-purchase misbehaviour. They (Babakus et al. 2004) tested their hypotheses according religion and nationality and came up to conclusion that religious affiliation has a significant impact on 10 out of 11 tested unethical behaviours. Also, their study showed significant national differences in perceptions towards consumer ethics.

Also a research on students in $8 \mathrm{EU}$ countries was conducted and pointed to differences in consumer ethics between Northern and Southern parts of Earthy concluded that the main difference between EU North and South relates to the way in which consumers perceive actively benefiting from illegal and questionable activities (see Polonsky et al. 2001). But also they (Polonsky et al. 2001) point out that respondents broadly perceive ethical issues in similar ways and they suggest that there is some standardization of consumers' views.

In Croatia there are some studies on CSR and consumer ethics attitudes. We will mention just a few of them. For instance, study (Skrabalo et al. 2007) assessed that in Croatia there were about 200 companies that accepted CSR as a part of their strategic orientation. These companies were mostly large, leading companies, with a significant share of foreign ownership, listed at stock market and export oriented; and they concluded that areas of CSR are mostly: quality and safety of work, customer satisfaction, environmental protection, and partnership in community.

Moreover, primary in-field research (Tipuric et al. 2005) explored the social awareness in business practice of Croatian managers and concludes: (1) larger proportion of Croatian managers that have affirmative attitude towards CSR and they think that CSR is part of their daily job and that CSR influence workers' motivation and devotion; (2) larger proportion of managers that have affirmative attitude towards CSR emphasis influence of external organizational factors while larger proportion of managers with neutral attitude emphasis internal organizational factors as stimulus for CSR.

In addition, CSR in Croatia is analysed in paper (Omazic 2008) and it is established that stakeholders' activities in Croatia were mostly reactive and focus to media which resulted in situation where companies thought of CSR as public relations and donations. He (Omazic 2008) stated that legal system was reactive in nature and didn't demand special efforts and concluded that there was no clear evidence in strategic sense that Croatian companies pay enough attention to CSR, even though growing number of companies thought of CSR as a business opportunity.

On the other hand, study (Renko et al. 2009) explore aspects of CSR in retail industry in Croatia 
together with some aspects of consumer ethics, especially, towards environmental aspects.

While in their primary research (Vrdoljak Raguz, Hazdovac 2014) found that companies in Croatia show some signs of corporate social responsibility, but they do not have a systematic CSR strategy and they usually focus on some segment of social responsibility. In addition, consumers recognize the term and the importance of social responsibility, although they do not give appropriate attention to it when selecting products.

\section{Methodology and sample}

Based on the literature review and previous research studies, a modified-questionnaire was developed. The questionnaire was structured into 6 sections. Questionnaire constructs and objectives of each section are given in the Table 1 .

Table 1. The structure of questionnaire (Source: own work)

\begin{tabular}{|c|c|c|c|}
\hline Section & $\begin{array}{c}\text { Number and } \\
\text { type of ques- } \\
\text { tions }\end{array}$ & Objective & $\begin{array}{l}\text { Literature } \\
\text { used for ques- } \\
\text { tion construct }\end{array}$ \\
\hline 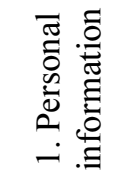 & $\begin{array}{l}3 \text {, single } \\
\text { choice }\end{array}$ & $\begin{array}{l}\text { Socio- } \\
\text { demographic } \\
\text { description of } \\
\text { respondents }\end{array}$ & $\begin{array}{l}\text { Modified ac- } \\
\text { cording to: } \\
\text { Renko et al. } \\
(2009)\end{array}$ \\
\hline 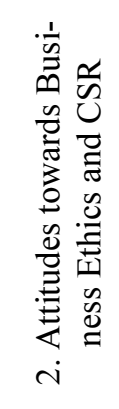 & $\begin{array}{l}30 \text { statements, } \\
\text { Likert scale }\end{array}$ & $\begin{array}{l}\text { to examine } \\
\text { general atti- } \\
\text { tudes towards } \\
\text { CSR issues }\end{array}$ & $\begin{array}{l}\text { ATBEQ as in: } \\
\text { Preble, } \\
\text { Reichel } \\
\text { (1988), } \\
\text { Shields et al. } \\
\text { (2013), Fato- } \\
\text { ki, Chillya } \\
(2012), \\
\text { Bageac et al. } \\
(2011)\end{array}$ \\
\hline 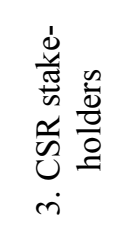 & $\begin{array}{l}\text { 1, single } \\
\text { choice } \\
4 \text { statements, } \\
\text { Likert scale }\end{array}$ & $\begin{array}{l}\text { to investigate } \\
\text { the perception } \\
\text { of importance } \\
\text { of stakehold- } \\
\text { ers groups }\end{array}$ & $\begin{array}{l}\text { own construct } \\
\text { based on liter- } \\
\text { ature review } \\
\text { described in } \\
\text { chapter } 2.2 . \text { of } \\
\text { the paper }\end{array}$ \\
\hline 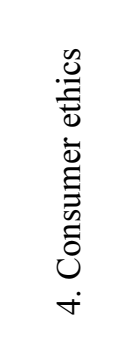 & $\begin{array}{l}3, \text { single } \\
\text { choice } \\
7 \text { statements, } \\
\text { modified Lik- } \\
\text { ert scale }\end{array}$ & $\begin{array}{l}\text { to evaluate } \\
\text { ethics of be- } \\
\text { haviour of } \\
\text { young con- } \\
\text { sumers in } \\
\text { retail }\end{array}$ & $\begin{array}{l}\text { Selected ques- } \\
\text { tions from } \\
\text { CES - } \\
\text { Muncy, Vitell } \\
(1992) \text {; Baba- } \\
\text { kus et al. } \\
(2004), \\
\text { Polonsky } \\
\text { et al. }(2001)\end{array}$ \\
\hline
\end{tabular}

An online questionnaire included questions of different types: one choice question, multiple choice questions and Likert scale ranking questions. As in this paper we will focus on the results gathered out of third, fourth and fifth section of the survey, in advance we will describe the literature used for those parts and we will focus on interpretation of the findings gathered only in those sections of survey.

The digital questionnaire was distributed through social networking platform - official Facebook groups of courses and Google Classrooms to students at various years of study of study programmes in Business Administration and Economics in Croatia. Those students were selected as a prospects future managers, based on findings of previous studies (such as Preble, Reichel 1988; Shields et al. 2013; Bageac et al. 2011; Claar et al. 2012).

The main objectives of the survey were: (1) to understand how students as future managers perceive CSR in general, (2) which stakeholders do they perceive as important and (2) to investigate what are their attitudes towards consumer ethics issues.

Table 2. Sample characteristics, $N=224$

(Source: own work)

\begin{tabular}{l|l|c}
\hline \multicolumn{1}{c|}{ Characteristic } & \multicolumn{1}{|c}{ Options } & $\begin{array}{c}\text { Relative } \\
\text { Frequency }\end{array}$ \\
\hline \multirow{2}{*}{ Gender } & Males & $22.3 \%$ \\
& Females & $77.7 \%$ \\
\hline \multirow{3}{*}{ Study programme } & Bachelor & $38.8 \%$ \\
& Master & $22.8 \%$ \\
& Postgraduate & $0.4 \%$ \\
& Associate & $37.9 \%$ \\
\hline \multirow{3}{*}{ Employment } & I usually work & $32.1 \%$ \\
& I work occasionally & $37.5 \%$ \\
& I don't work & $30.4 \%$ \\
\hline
\end{tabular}

The sample consists of 224 respondents. As shown in Table 2, there were $77.7 \%$ of female and $22.3 \%$ of male students at the sample. The gender structure of the sample was in the accordance to the student population within faculties of business administration and economics in Croatia. All respondents are students enrolled in various study programmes in mentioned fields, $38.8 \%$ are at bachelor level, $22.8 \%$ at master level, $37.9 \%$ in associate degree programmes, and only a couple of them are at postgraduate studies.

Almost $70 \%$ of them work usually or occasionally, while $30.4 \%$ are exclusively study and not working at all. 


\section{Results and discussion}

Even though the questionnaire was complex and included 48 questions or statements (see Table 1), for the purposes of this article will not analyse all of them, but we will select only those which directly emphasize students' attitudes towards CSR practices and students' consumer ethics.

\subsection{General attitudes towards CSR and busi- ness ethics}

In the Second Section of the Questionnaire put some general questions on CSR as a business concept. In Figure 1 the general attitudes of respondents towards CSR are shown. A high proportion expressed that modern society demands from companies to solve social problems $(64.7 \%$ agreed and strongly agreed to this statement), also they understand that companies committed to CSR have a potential to be more profitable on a long run $(69.2 \%$ agreed and strongly agreed to this statement). But the most interesting thing is expressed will on working for a company with implemented Sustainability and CSR concepts (here 79.4\% agreed and strongly agreed to this statement).

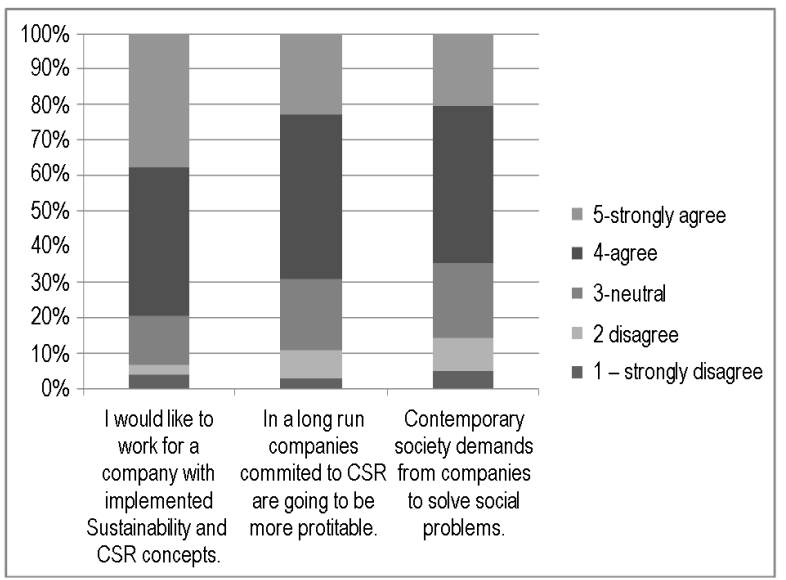

Fig. 1. General attitudes towards CSR (Source: own work)

Then we applied a scale according to ATBEQ (Attitudes Toward Business Ethics Questionnaire), we included all 30 statements and respondents had to state agreements on Likert scale from 1 strongly disagree to 5 - strongly agree. But, for the purpose of this paper we analysed only 10 questions. Results are shown in Figure 2. Out of analysed questions, the strongest disagreement respondents expressed to the statement "Moral values are irrelevant to business world" and "Business Ethics is a concept for public relations". While strongest agreement was expressed to the statements "The business world has its own rules." And "True morality is the first and foremost self-interest."

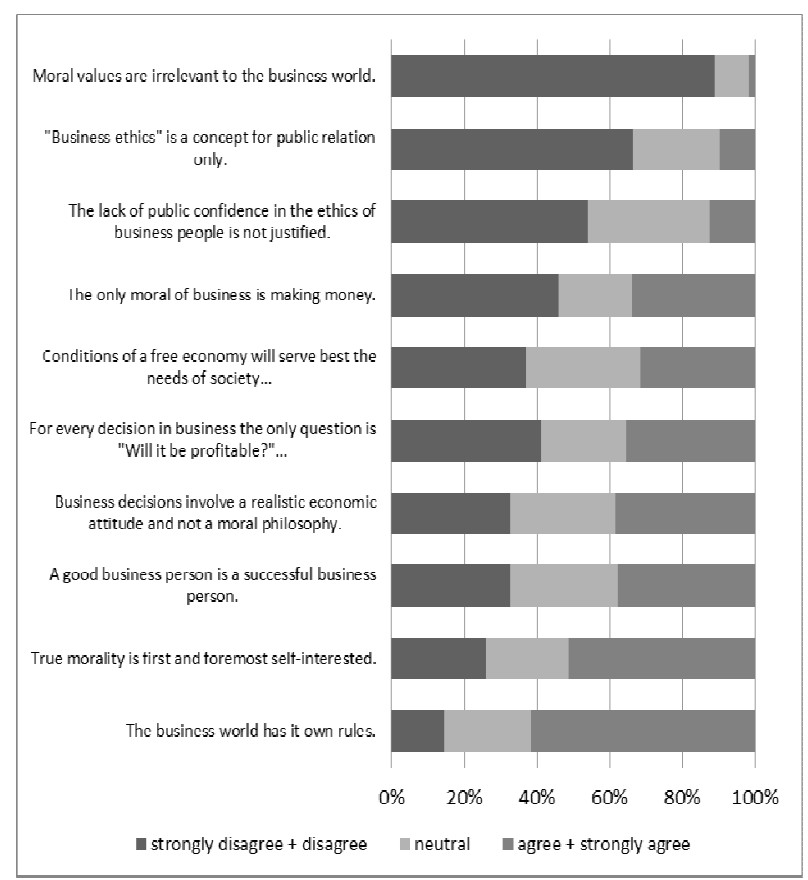

Fig. 2. Attitudes towards business ethics (Source: own work)

\subsection{Perception on CSR stakeholders}

Questions on perception on stakeholders were in two sections of the questionnaire. In the Second Section respondents evaluated do "Companies have ethical responsibility towards all stakeholders." And they expressed high level of agreement with those statements $60.7 \%$ of them evaluated chosen options agree $(40.2 \%)$ and strongly agree $(20.5 \%)$. Anyhow, there were $23.7 \%$ respondents with neutral opinion.

In Third Section of the questionnaire they were asked to evaluate who is the most important CSR stakeholder. As the basis of stakeholders' classification we used typology given in literature (see Evans, Sawyer 2010). In Figure 3 the perception on this question is showed. It can be observed that respondents evaluate consumer, employees and local community and environment as equally important CSR stakeholders as each group was evaluated with around $30 \%$ to be the most important. This fully confirms their opinions from the Second Section of the Questionnaire.

There is one more statement that was evaluated in the Second Section regarding CSR stakeholders: "The main goal of stakeholders is to maximize return on their interests." and respondents expressed high level of agreement $(71.4 \%$ chosen agree or strongly agree, and the average grade is 3.83 out of maximum 5). 


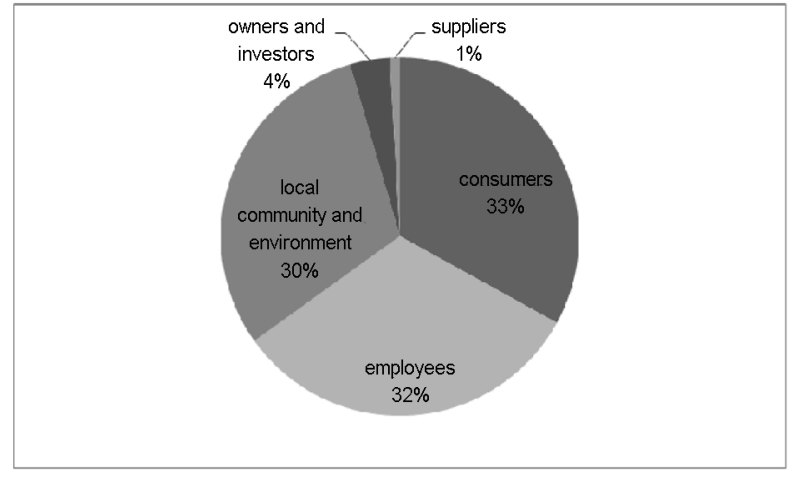

Fig. 3. Perception of students on the most important CSR stakeholder

(Source: own work)

\subsection{Students' consumer ethics}

The last section of the questionnaire included questions on shopping misbehaviour and partially it was adapted according to Consumer Ethics Scale (CES) and findings given in literature (see Babakus et al. 2004). Figure 4 shows evaluated frequencies of shopping malpractices. According to this finding, we can conclude that intentionally making a damage to get a discount is the most unaccepted malpractice, followed by consuming a product in-store without paying for it. While cutting in a line at cashier desk and searching information on one place for products to be bought at another are more accepted malpractices in the sample of our research.

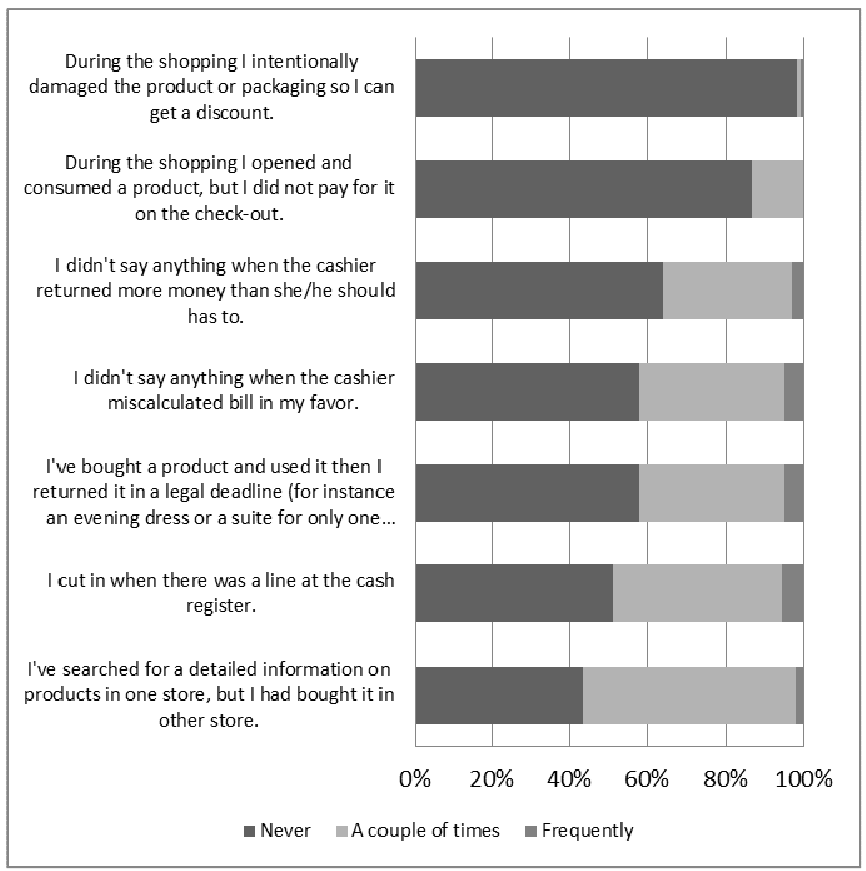

Fig. 4. Frequency shopping malpractices (Source: own work)
In addition, respondents were asked what do they expect in return for their ethical action while in shopping (for instance when telling cashier that she/he returned more money than she/he should, or when help someone...). More than a half of respondents (see Fig. 5) claim that they do not expect anything because it makes them satisfied, 38\% wants only some kind of appraisal, while only $8 \%$ prefer some kind of material award (such as products, discounts or cash).

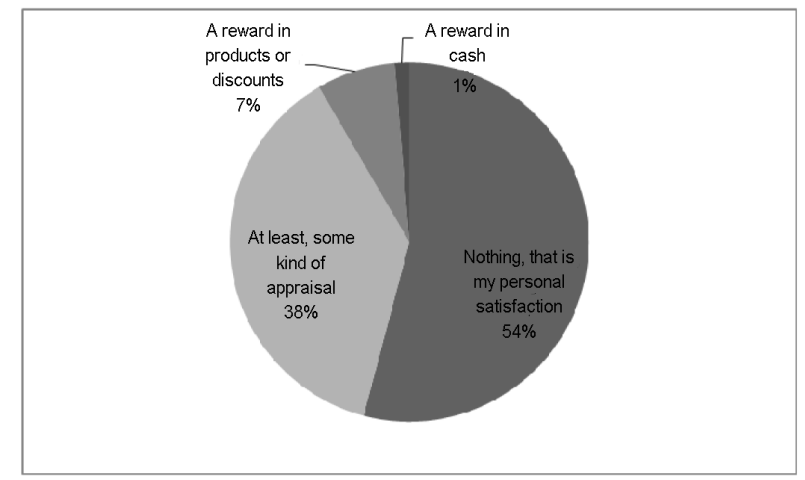

Fig. 5. Expected rewards for active ethical behaviour in shopping (Source: own work)

As in Croatia shopping malls are opened on Sunday, and there are many argues that are going on ethics of this topic, as in Croatia more than $80 \%$ of population declares as Roman Catholics, in this questionnaire we put two question in order to test attitudes of young consumers regarding this issue. The first one was: "Do you visit shopping malls on Sunday?" and the second was: "Would you be willing to work on Sundays?" the finding are showed at Figure 6 and 7. On the basis of presented results, we can conclude that in a group of young consumers Sunday is still evaluated as a

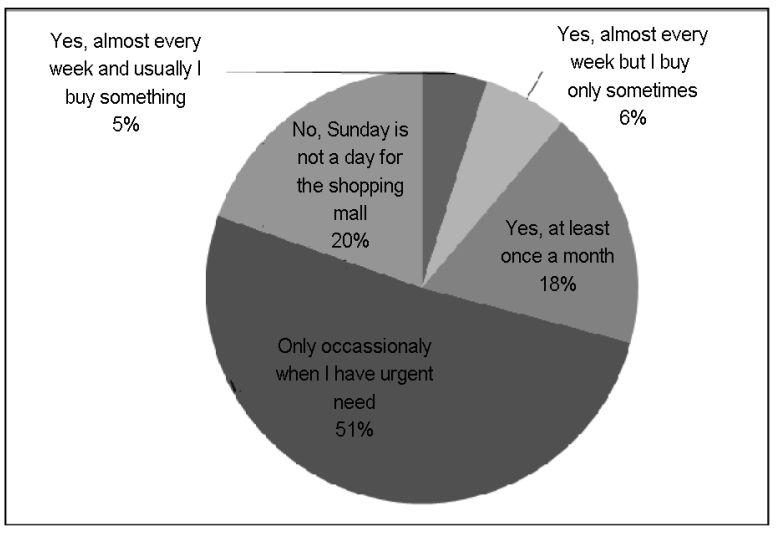

Fig. 6. Summary of answers to question: "Do you visit shopping malls on Sunday?"

(Source: own work) 
special day (only $11 \%$ of them visit malls on Sunday on weekly basis, and it is interesting that only $6 \%$ of them is actually making purchases; and 35\% would prefer some benefit of working on Sunday, $13 \%$ do not want to work on Sunday by any means, while $45 \%$ evaluate economic situation as the most important factor when deciding on working Sunday).

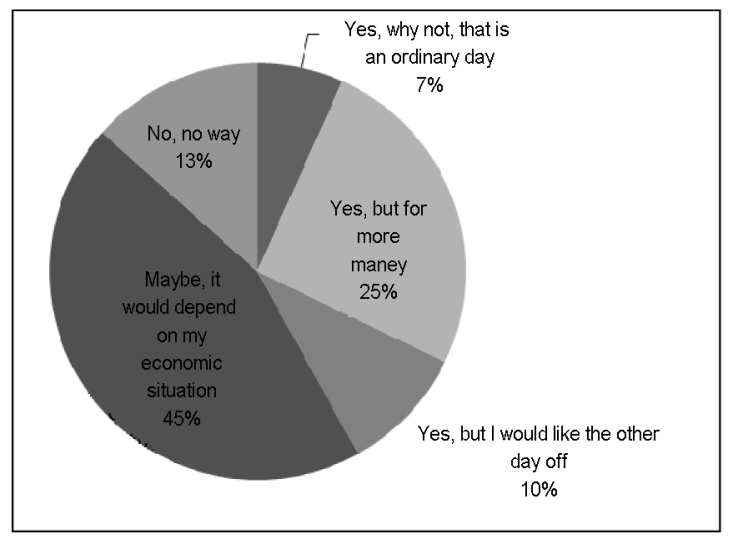

Fig. 7. Summary of answers to question: "Would you be willing to work on Sundays?"

(Source: own work)

\section{Limitations}

The intentional focus of this research study was to better understand the perceptions of young consumers towards CSR and consumer ethics. Applied approach can raise considerations for interpreting the study data. The research may not be representative for the whole young population as only Business Administration and Economics students are in the focus of the survey, but similar approach was used in other research studies in other countries (for illustration see Preble, Reichel 1998; Bageac et al. 2011; Claar et al. 2012).

In addition, this study is a one-time snapshot; therefore, longitudinal study could provide more valuable insight into changes of attitudes towards CSR and consumer ethics over time.

\section{Conclusions}

CSR and consumer ethics are two research fields broadly covered with literature and research studies. Anyhow, in Southern Eastern Europe there is scarcity on research studies on attitudes on those two topics.

The aim of the paper was to evaluate perception of young consumers and future managers towards ethical principles that are the basis of CSR and consumer ethics. Among all, we have found out that this population:

- understands that contemporary society demands from companies to solve social problems.

- perceives that companies committed to CSR have a potential to be more profitable on a long run.

- believes that Business Ethics is not a concept for public relations only (i.e. it is a real concept).

- thinks that companies have ethical responsibility towards all stakeholders.

- would prefer to work for a company with implemented Sustainability and CSR concepts.

When we come to consumer ethics, we can observe that they have high personal ethical standards as a large number of shopping malpractices is not accepted and applied in their behaviour. Moreover, if they take an ethical action, majority of them do not expect any material reward.

As a significant number of questions in this research were adapted from ATBEQ (Attitudes Toward Business Ethics Questionnaire) and Consumer Ethics Scale (CES), in future the research finding can be further scrutinized and explained in detail by correlating findings from Croatia to those presented for other countries such as USA, Egypt, Israel, South Africa etc.

\section{Acknowledgements and Funding}

This work has been supported by

$$
\begin{aligned}
& \text { Croatian Science Founda- } \\
& \text { tion under the project } \\
& \text { UIP-2014-09-4057 "Po- } \\
& \text { tentials and obstacles of }
\end{aligned}
$$

\section{Disclosure statement}

Authors declare that they do not have any competing financial, professional, or personal interests from other parties.

\section{References}

Al-Khatib, J. A.; Vitell, S. J.; Rawwas, M. Y. A. 1997. Consumer ethics: a cross-cultural investigation, European Journal of Marketing 31(11/12): 750 767. http://dx.doi.org/10.1108/03090569710190514

Alrousan, M. A.; Bader, M. A.; Abuamoud, I. 2015. Stakeholders approach in influencing corporate social responsibility: a case study at two hotels in 
Jordan, International Journal of Tourism Policy 6(1): 17-28.

http://dx.doi.org/10.1504/IJTP.2015.075135

Babakus, E. T.; Cornwell, B.; Mitchell, V.; Schlegelmilch, B. 2004. Reactions to unethical consumer behavior across six countries, Journal of Consumer Marketing 21(4): 254-263.

http://dx.doi.org/10.1108/07363760410542165

Bageac, D.; Furer O.; Reynaud, E. 2011. Management students' attitudes toward business ethics: a comparison between France and Romania, Journal of Business Ethics 98(3): 391-406. http://dx.doi.org/10.1007/s10551-010-0555-5

Bosch-Badia, M. T.; Montllor-Serrats, J.; Tarrazon, M. A. 2013. Corporate social responsibility from Friedman to Porter and Kramer, Theoretical Economics Letters 2013 (3): 11-15.

Branko, C. M.; Rodrigues, L. L. 2007. Positioning stakeholder theory within the debate on corporate social responsibility, Electronic Journal of Business Ethics and Organization Studies 12(1): 5-15.

Business Impact. 2000. Winning with integrity: a guide to social responsibility [online]. Business in the Community, London [cited 4 October 2015]. Available from Internet: http://www.orendaconnec tions.com/Winning-with-integrity-Summary.pdf

Carrigan, M.; Attalla, A. 2001. The myth of the ethical consumer - do ethics matter in purchase behaviour?, Journal of Consumer Marketing 18(7): 560-578. http://dx.doi.org/10.1108/07363760110410263

Carroll, A. B. 1979. A three-dimensional conceptual model of corporate performance, Academy of Management Review 4(4): 497-505.

Cheng, W. L.; Ahmad, J. 2010. Incorporating stakeholder approach in corporate social responsibility (CSR): a case study at multinational corporations (MNCs) in Penang, Social Responsibility Journal 6(4): 593-610. http://dx.doi.org/10.1108/17471111011083464

Claar, V. V.; Frey, R.; Szarucki, M.; TenHaken, V. R. 2012. Hope for the East: entrepreneurial attitudes of MBA students in two transition economies relative to those in the USA, International Journal of Business Excellence 5(3): 220-237. http://dx.doi.org/10.1504/IJBEX.2012.046640

Ditlev-Simonsen, C.; Wenstop, F. 2013. How stakeholders view stakeholders as CSR motivators, Social Responsibility Journal 9(1): 137-147. http://dx.doi.org/10.1108/17471111311307868

European Commission. 2002. Corporate social responsibility [online], [cited 2 February 2016]. Available from Internet: http://trade.ec.europa.eu/doclib/ docs/2006/february/tradoc_127374.pdf

Evans, N.; Sawyer, J. 2010. CSR and stakeholders of small businesses in regional South Australia, Social Responsibility Journal 6(3): 433-451. http://dx.doi.org/10.1108/17471111011064799
Fatoki, O.; Chillya, W. 2012. An investigation into the attitudes towards business ethics and corporate social responsibility by local and immigrant SME owners in South Africa, Journal of Social Sciences 32(1): 13-21.

Holbrook, M. B. 1994. Ethics in consumer research: an overview and prospectus in C. T. Allen, D. Roedder, J. Provo (Eds.). Advances in consumer research, Vol. 21. UT: Association for Consumer Research, 566-571.

Hopkins, M. 2005. Measurement of corporate social responsibility, International Journal of Management and Decision Making 6(3-4): 213-231. http://dx.doi.org/10.1504/IJMDM.2005.006549

Hunt, S. D:, Vitell, S. 1986. A general theory of marketing ethics, Journal of Macromarketing 6(1): 516. http://dx.doi.org/10.1177/027614678600600103

ISO 26000. Social capital for Economy [online], [cited 3 February 2016]. Available from Internet: https://www.iisd.org/standards/csr.asp

Knezevic, B.; Sukser, B.; Renko, S. 2012. Historical aspects of sustainable development in trade, in The International Conference Proceedings - Trade Perspectives 2012: Trade in the Context of Sustainable Development, 21-22 November 2012, Zagreb, Croatia, 1-18.

Kotler, P.; Keller, K. L. 2006. Marketing management. 12 ed. New Jersey: Pearson Education Inc.

Moir, L. 2001. What do we mean by corporate social responsibility?, Corporate Governance 1(2): 1622. http://dx.doi.org/10.1108/EUM0000000005486

Moore, D.; Vamvakidis, A. 2007. Economic growth in Croatia: potential and constraints, IMF Working Paper WP/07/198. International Monetary Fund.

Muncy, J. A.; Vitell, S. J. 1992. Consumer ethics: an investigation of the ethical beliefs of the final consumer, Journal of Business Research 1(24): 297-311. http://dx.doi.org/10.1016/0148-2963(92)90036-B

Nguyen, L.; Pham, L. N. T. 2015. Business students and ethics: a cross-cultural study between the U.S. and Vietnam, S.A.M. Advanced Management Journal 80(4): 31-44.

Omazic, M. A. 2008. Društvena odgovornost poduzeća i korporativno upravljanje [Corporate Social Responsibility and Corporate Management], in D. Tipuric (Ed.). Korporativno upravljanje [Corporate Management], Zagreb: Sinergija, 323-360.

Peloza, J. 2006. Using corporate responsibility as an insurance for financial performance, California Management Review 48(2): 52-72.

http://dx.doi.org/10.2307/41166338

Polonsky, M. J.; Brito, P. Q.; Pinto, J.; Higgs-Kleyn, N. 2001. Consumer ethics in the European Union: a comparison of Northern and Southern Views, Journal of Business Ethics 31(2): 117-130. http://dx.doi.org/10.1023/A:1010780526643 
Preble, J. F.; Reichel, A. 1988. Attitudes towards business ethics of future managers in the U.S. and Israel, Journal Business Ethics (7): 941-949.

Preston L.; Bannon, P. 1997. The corporate socialfinancial performance relationship, Business and Society 36(1): 5-31.

Renko, S.; Rasic, S.; Knezevic, B. 2009. Corporate social responsibility in Croatian retailing in D. Vrontis, Y. Weber, R. Kaufmann, S. Tarba (Eds.). Managerial and entrepreneurial developments in the mediterranean area. Salerno: EuroMed Press, 1346-1358.

Rudawska, E.; Witkowska, A. 2012. Social responsibility as a determiner of relations with trade partners, in The International Conference Proceedings Trade Perspectives 2012: Trade in the Context of Sustainable Development, 21-22 November 2012, Zagreb, Croatia, 89-101.

Ruf, B. M.; Muralidhar, K.; Brown, R. M.; Janney, J. J.; Paul, K. 2001. An empirical investigation of the relationship between change in corporate social performance and financial performance: a stakeholder theory perspective, Journal of Business Ethics 32(2): 143-156.

http://dx.doi.org/10.1023/A:1010786912118

Scott, S. 2007. Corporate social responsibility and the fetter of profitability, Social Responsibility Journal 3(4): 31-39. http://dx.doi.org/10.1108/17471110710840215

Shaw, N. 1999. Trade and sustainable development, in K. S. Bawa, R. Seider (Eds.). Dimensions of Sustainable Development, Vol. 1: Encyclopedia for life support systems. UNESCO, 169-223.

Shields, R.; Comegys, C.; Lupton, R.; Takei, H. 2013. Undergraduate attitudes towards business ethics: a cross-cultural comparison, Journal of Studies in Education 3(4): 72-80. http://dx.doi.org/10.5296/jse.v3i4.4179

Skrabalo, M.; Miosic-Lisjak, N.; Bagic, A. 2007. Ubrzanje praksi društveno odgovornog poslovanja Izvještaj o društveno odgovornom poslovanju $u$
Hrvatskoj [Acceleration of Corporate Social Responsibility - Report on Corporate Social Responsibility in Croatia], United Nations Development Programme (UNDP): Zagreb [online], [cited January 2016]. Available from Internet:

https://issuu.com/undphr/docs/ubrzanje_praksi_dru tveno_odgovorn

Stanwick, P. A.; Stanwick, S. D. 1998. The relationship between corporate social responsibility and organizational size, financial performance and environmental performance: an empirical examinations, Journal of Business Ethics 17(2): 195-204. http://dx.doi.org/10.1023/A:1005784421547

Sun, L.; Stuebs, M. 2013. Corporate social responsibility and firm productivity: evidence from the chemical industry in the United States, Journal of Business Ethics 118(2): 251-263. http://dx.doi.org/10.1007/s10551-012-1579-9

Szarucki, M. 2013. Determinants of corporate social responsibility application in Polish SMEs, in R. Borowiecki, A. Jaki, T. Rojek (Eds.). Contemporary economies in the face of new challenges. Economic, social and legal aspects. Cracow: Foundation of the Cracow University of Economics, 117-131.

Tipuric, D.; Omazic, M. A.; Hruska, D. 2005. Corporate social responsibility and Croatian managers - empirical study, in D. Kantarelis (Ed.). Global business \& economics review - anthology 2005. Worcester, 289-300.

Vitell, S. J.; Singhapakdi, A.; Thomas, J. 2001. Consumer ethics: an application and empirical testing of the Hunt-Vitell theory of ethics, Journal of Consumer Marketing 18(2): 153-178. http://dx.doi.org/10.1108/07363760110386018

Vrdoljak Raguz, I.; Hazdovac, K. 2014. Društveno odgovorno poslovanje i hrvatska gospodarska praksa [Corporate Social Responsibility and Croatian Business Practice], Oeconomica Jadertina 4(1): 40-58. 